\title{
Curriculum Reforms for Entrepreneurship Education and Quality Human Life
}

\author{
Sam Oluseyi Oyekan, PhD \\ Department of Special Education \& Curriculum Studies, \\ Adeyemi College of Education, Ondo, Nigeria.
}

\begin{abstract}
Curriculum is the hard core of education that provides the basic contents and means of relevant knowledge, skills and attitudes for sustainable development. Schools are the generational educative agencies which would impart the functional learning experiences required to refine and nurture learners into productive manpower for technological advancement, industrial development and economic growth of the nation. The purpose of this paper is to highlight the relevance of curriculum reforms in the facilitation of educational innovations, entrepreneurial training and wealth creation for quality human life. It will be construed as a potent platform to seek and resolve prevailing problems associated with access to quality education, human capacity building, selfreliant employment opportunities and welfare of the citizenry. The school curriculum should provide a diversity of learning contents, creative innovations, professional standards and industrial experiences that will maximize the talents of learners, generate job opportunities and cater for the critical needs of self-reliant society. Hence, it is suggested that an increased access and funding of comprehensive education, distillation of entrepreneurial initiatives into the subject curricula, and the building of school-industry-community relationships and partnerships shall enhance continuing production of competent and responsive school graduates into the world of work. Such an educated workforce will have the capacity and capability to drive social, political, industrial and economic development for shared prosperity and quality of human life.
\end{abstract}

Keywords: Education, curriculum, entrepreneurial initiatives, creative innovations, prosperity, workforce, economy, sustainable future.

\section{Introduction}

Since the divine creation of human beings, education has been adopted essentially as a reformative process in sustainable development of a dynamic society for shared prosperity and harmony of the citizenry (Adamu, 1994; Awofala \& Sopekan, 2013; Oyekan, 2015). The potency of quality education makes progressive nations across the world to use the school curriculum for intellectual and vocational engagements of learners as a means of nurturing the required manpower needs in public and private sectors of the economy. This implies that the comprehensive school curriculum should reflect creative interests, new ideas and viable aspirations as well as vibrant cultural heritage, technological advancement, innovative industrial experiences and entrepreneurial needs of the contemporary society. In Oyekan's (2015) view, survival of such a dynamic human organisation is essentially anchored on sound education, training, induction and orientation of its people into their chosen professions. It is predicated on the conviction that functional education is the most enduring investment, legacy and tool for our future generations to pursue a common cause of development and advancement in all aspects of humanity.

Changing economic, social and political situations in both developed and developing countries have combined to create needs for constant innovations and reforms in education (Adamu, 1994). Such impactful changes might result from sufficient exploitation of valuable natural resources, provision of equal opportunities for school-age children, search for a more efficient strategy of achieving educational objectives, adoption of technology and engineering devices, desire for competent and productive manpower, massive failure in organised examinations, increasing unemployment, the scourge of corruption, leadership failure and the rising tides of poverty and insecurity across the nation. These multidimensional problems could become educational issues which may be configured into practical tasks for curriculum research and reforms in primary, secondary and tertiary institutions. Becoming real solutions to human capital development for quality assurance in all aspects of our national life, Engelberger (1982) noted that innovations require three basic things: 
A recognised need,

Competent people with relevant technology (and morality), and

\section{Steady financial support.}

From the above disclosure, organised instructional practices would require effective coordination of resources and efforts of teachers, students and support staff towards consistent renewal of curriculum contents, materials, methods and assessment procedures. The tendency is to adopt supportive innovations, integrate technological devices and improve the strategic provision of functional education at all levels of schooling. Educational stakeholders should craft and implement sound curriculum development plans, and instructional programmes that will leverage their natural endowments to invest in human capital, practical agriculture, solid minerals, power, sports and tourism towards nurturing a broad-based economy with productive activities for industrialisation, job creation and revenue generation.

The nation's education system is, therefore, expected to provide the children and youths with basic insights, skills and attitudes relevant to living and coping with emerging industrial economy in a knowledge-driven society. A desirable curriculum represents the selection of knowledge and experiences deemed valuable by a particular society at a specific stage of its historical evolution (Kwong \& Kooi, 1990). While the curriculum is recognised as the heart of education, curriculum reform could be regarded as a change response for diagnostic remediation of identified challenges in schooling, economy and society. It is, therefore, instructive to note that these critical imperatives of curriculum reform will necessitate the need for school curriculum improvement. Which is why the curriculum reform becomes a means of transformation to enhance the quality of professional training, learning enhancement, manpower development and leadership vision for good governance, economic growth and shared prosperity of the citizenry? Effective performance of competent teachers might, therefore, require adequate professional education, expertise, orientation, integrity and discipline with an exemplary cordiality and commitment to best practices in human resource development. This may be complemented with industrial skills gap assessment to identify the quantity, availability and utility of such abilities to enhance employability of school graduates, poverty alleviation and healthy life.

Hence, this paper examines the role of curriculum reforms for entrepreneurship education and quality human life. The purpose is to highlight the relevance of curriculum reforms in the facilitation of educational innovation, vocational competence, entrepreneurial training and wealth creation for the wellbeing of mankind. It will be construed as a potent platform to seek and resolve prevailing problems associated with equal access to quality education, human capacity building, self-reliant employment opportunities and welfare of the citizenry. Efforts shall be made to highlight the basic challenges, strategies and prospects of curriculum reforms for human capital development. The relationship between curriculum reforms and entrepreneurship education may provide the basis for professionalisation and vocationalisation of learning contents. It could strengthen the school graduates with employable competence, productivity and work ethics that would make them self-reliant and self-fulfilled individuals.

\section{Challenges of Curriculum Reforms}

A school curriculum is a socially-constructed response to perceived issues and demands in the society (Kwong and Kooi, 1990). It is central both to the enterprise of education and the image which the society wishes to project of its past, present and desired future. In past colonial developing countries such as Nigeria, education which is denominated on meaningful schooling is severally regarded as an instrument of social reconstruction, economic prosperity and political stability (Oyekan, 2000). Emphasis is on the need to maximize and refine the potentials of human resources with a broad-based curriculum built on a core of basic academic subjects, pre-vocational studies and co-curricular activities. Its successful actualization severally demands a multitude of roles and virtues from good teachers and instructors as well as timely resolution of resource and logistics challenges at all stages of curriculum reforms.

Challenges of curriculum reforms are nearly proportional to the series of problems associated with inequitable infrastructural provision, limited accessibility to quality education, brazen corruption, ravenous poverty and stressful insecurity across the world. It implies that education which is supposed to be an enduring catalyst for capacity building and utilization in all fabrics of the society appears to be enmeshed in a network of avoidable contradictions and crises (Oyekan, 2000). An x-ray of problems which could hinder curriculum reforms in Nigerian schools (Kwong and Kooi, 1990; Adamu, 1994; Oyekan, 1997, 2015) includes: 
Inadequate funding of education and training programmes at all levels of schooling;

Dearth of suitably trained and qualified professional teachers in vocational, technical and core subjects;

Insufficiency of functional modern educational facilities typified by well-equipped classrooms and workshops, well-stocked libraries and laboratories as well as durable Internet and recreational resources;

Undue interference of cultural, ethnic, religious and political considerations in educational matters;

Paucity of innovative educational research works for accurate data collection and analysis, effective teaching and problem solving for national development;

Increasing student population that results in large class size and heavy work load for teachers and support staff;

Inadequate school-industry-community partnerships and integration of formal and indigenous education systems for selfreliance and employability of school graduates;

Lingering social, economic and political crises with impact on education and society;

Intrusion of schools by social vices such as corruption, cultism, drug abuse, examination malpractices, sexual harassment and vandalisation of infrastructural facilities ;

Insufficient sponsorship of educational staff to attend regular in-service training programmes aimed at enhancing currency of subject matter, pedagogy, professionalism, productivity and excellence in service delivery;

Resistance of some educational professionals towards global curriculum innovations and blended learning devices;

High unemployment rate, weak socio-emotional abilities, and aversion towards education and training;

Inadequate school inspection and instructional supervision for quality assurance in education;

Scarcity of quality textbooks, journals, magazines and manuals to support the curriculum reforms in schools;

Insufficient reliable database of available skills for capacity building and opportunities in labour market; and

Inadequate involvement of relevant regulatory bodies and training institutes for improving and guiding skills' trainers.

From the foregoing, curriculum tasks have been entangled in a spate of avoidable inadequacies and unethical practices that can hinder the corporate existence of educational institutions, erode the credibility their awarded certificates, and impair the employability of the school graduates (Oyekan, 1997). A number of factors that culminate in crises in education and consequently hinder curriculum reforms are often precipitated by inadequacies of students, parents, governments, educational supervisory agencies, regulatory professional organisations, examination bodies, private sector, and the Nigerian society. These constraints should be removed with priority attention to qualitative education in this era of globalisation, which demands a consensus on the importance of collective management of cross-border issues such as commerce, vocational education, employment, environment, narcotics and terrorism.

For schools to cope with the dynamic global challenges and best practices for quality human life, curriculum improvement should embrace the current changes towards professionalisation, vocationalisation and integration of technological devices into Nigerian educational system. The tendency is to promote blended learning and entrepreneurship education by enhancing the provision of generative knowledge, enterprising skills and professional standards which can develop the creative talents of learners and increase their chances of creating or securing gainful jobs. It becomes expedient to enrich the schools with sufficient funds, modern infrastructural facilities, and competent manpower that could provide meaningful science, technology, humanities, and management programmes for a broad spectrum of learners with varying needs.

\section{Strategy for Functional Curriculum Reforms}

Curriculum is the hard core of education that provides the basic contents and means of relevant knowledge, skills and attitudes for sustainable development and shared prosperity of the citizenry (Oyekan, 1997). This is why schools are the generational educative agencies which would impart the functional learning experiences required to refine and nurture learners into productive manpower for technological advancement, industrial development and economic growth of the nation. It implies that quality education should aim at the creation of a new society of educated people who will continually 
adopt practical reasoning, critical dialogue, creative production of things and preventive diplomacy in rational resolution of human and environmental problems. The corollary is that emphasis should be placed on functional education which will spur learners to engage in creative thinking, analyse emerging issues, solve attendant problems as well as construct useful things, render innovative services, and harness the natural resources of their living environment. As such practical education and entrepreneurial orientation develop their potentials and biodiversity to accomplish individual and national needs, our schools would have trained well-qualified boys and girls to become diligent and responsible professionals in all human disciplines. These inspiring leaders with new insights and perspectives for a new world will help in tapping and preserving the nation's wealth for social, economic and political development of the country.

Historical antecedents and contemporary realities of curriculum reforms result from earlier missionary and community involvements in education, curriculum improvements and policy statements of the Nigerian government in tandem with the globalising world. The basic characteristics and procedures of any curriculum reform efforts can be explained and understood within the context of curriculum theories, infrastructural needs, industrial skills gap assessment, and human capital development for effective citizenship in a global learning community for all. A viable curriculum reform might evolve from a critical review of the Nigerian education system vis-à-vis the contemporary demands of nation building and preparation of productive citizenry for happy and useful living in the society. It involves a series of wide consultations, constructive dialogue, incisive educational conferences and pragmatic curriculum workshops to fine tune emerging ideas, interests, needs and visions of learners, parents, governments, industries and the communities constituting the nation. This is in consonance with the classical National Curriculum Conference held in the University of Lagos, Lagos from $8^{\text {th }}-12^{\text {th }}$ September, 1969. It was a universal forum of all educational stakeholders adopted by the Federal Government to ruminate on a legion of public criticisms and discontent with the effectiveness of our education system, and to suggest a viable functional schooling pattern within the context of our cultural heritage, and national resources. Herein the purposeful conference emanated from the prospective windows of developmental opportunities created after the Second World War in 1945; colonial rule up to independence on 1st October, 1960 and post-independence era, which witnessed the proliferation of schools and industries; and the critical need for substantial manpower resources to manage the new independent government, increasing school-age children and growing national economy (Oyekan, 2015). A clear necessity to forge a new strategic direction in curriculum reform therein arose from a national outlook to review the prevailing education system for relevance in self-reliant manpower training, technological advancement, industrial development and economic growth of the country.

Hence, the Federal government was inspired to summon an inclusive seminar of distinguished educational experts, seasoned teachers, erudite scholars and accomplished professionals from a wide range of interests in 1973. The motive was to diversify the school curriculum, make it relevant to the varying needs and aspirations of individuals, and respond to the global realities of the modern world and rapid changes in Nigerian society for sustainable development. Between 1972 and 1976, a critical review of the Nigerian education system vis-à-vis the contemporary demands of nation building and productive citizenry was fine tuned with a series of insightful curriculum workshops on critical issues generated at the conference. The Conference Report largely provided the groundwork for the articulation of national policy guidelines on standards, procedures, strategies and innovations for the coordination of roles of stakeholders to ensure and sustain the delivery of qualitative education in Nigeria (Federal Republic of Nigeria, 2013). Much more significant and impactful educational decisions of the report severally led to the maiden publication of the National Policy on Education (NPE) in 1977; and subsequent reviewed editions in 1981, 1998, 2004 and 2013 respectively. Expected improvements in the education system embedded in the NPE were intended to keep with the contemporary realities of our living environment, dynamics of social change and the need to address noticeable gaps and provisions for modern advancements in the world of education and work.

A cursory look at the human society and schooling system will show that education has become a powerful tool necessary to unlock and nurture inherent human potential and vision for the resolution of economic, social and political challenges confronting the unity, stability and survival of Nigeria. This lends credence to the belief of World Bank (2016) that education is one of the most powerful instruments for reducing poverty and inequality, and lays a foundation for sustained economic growth. Educated people shall be regarded as those well-informed competent persons whose states of mind and behaviour naturally exhibit insightful ideas, creative skills and core values of humanity for quality life. A broad education should, therefore, prepare functional people who are fully integrated with their community to earn gainful living and promote rural transformation through peaceful co-existence. Enhancement of vocational competence, good habits and industrial experiences can largely promote functional self-reliance, mutual trust in learning and working environments, family 
cohesion, social justice, poverty alleviation and stable polity in a democratic society (Oyekan, 1997). It is reasonable to infer that the countries which embrace a qualitative education, preserve their cultural heritage, and value an enlightened society usually have productive self-reliant citizens necessary to diversify the economy, manage technological change, and sustain a democratic leadership. Such vibrant fellows shall foster systemic thinking and development of new skills for sustainable future work and business operations.

The increased demand for comprehensive education, sustainable self-reliance and entrepreneurial training might inspire the need to make the curriculum functional, child-centred and job-oriented by relating it to specific individual aspirations, overall community needs, and key skill sets of future industries and economies. On this premise, functional schools at all levels of education system will have the capacity to accommodate a plethora of advances in human knowledge, technological innovations, industrial productions and environmental challenges in diversified curricula for learners of varying potentials and career prospects. Emerging classroom practices should explore effective learning of generative ideas, creative abilities and core values of human survival without borders amidst today's global realities of technological trends and economic frameworks. Such a focused vision of inclusive education may nurture brilliant, intelligent and competent manpower that could shape the labour market and revitalise the economy with viable opportunities for employment and wealth creation. As the dynamic society changes through the continuing process of modernity, the curriculum will equally change towards preparing individuals for the enterprising challenges of life today and tomorrow. This underlines the nexus between curriculum diversification and entrepreneurship education in the course of diagnosing and rectifying the necessary knowledge and skills gaps for training and partnership priorities across the neighbourhood schools, industries and communities. In all, emerging school graduates stand the chance of improved wellbeing and social status.

\section{Curriculum Reform and Entrepreneurship Education}

The world is fast changing and becoming increasingly literate and skilled in democracy, commerce, science and technology, industrialisation, socialisation, and environmental management for sustainable development and quality human life. In our collective resolve to advance and join the comity of developed nations, functional education remains the enduring focus and bedrock for sustainable national development. Nigeria would require a comprehensive humanistic curriculum to promote permanent functional literacy and numeracy, foster national unity and harmony, equip the students with gainful living and inculcate global best practices to cope with emerging challenges of our modern society (Oyekan, 1997, 2016; Federal Republic of Nigeria, 2013). Along this modest expectation, it is necessary to envision the nexus between the school curricula, curriculum reforms and entrepreneurship education within the developmental context of productive citizenry and transparent governance in a democratic society.

Curriculum is the totality of planned learning experiences which the learner will acquire under the guidance of approved educative agencies in order to realise his/her needs, interests and aspirations for the benefit and growth of the society (Oyekan, 1997). This connotes that curriculum is all the activities exposed to learners within and outside the school under the guidance of teachers to promote their mental, physical and moral wellbeing. Being the entire training programme which students should pass through, a comprehensive instructional exposure embraces academic, non-academic, social, cultural and recreational activities designed to enhance their total development. It is important to note that curriculum encompasses a wide variety of potential resources, professional standards and instructional practices which educators and teachers shall adopt in disseminating relevant knowledge, enterprising skills and desirable attitudes to nurture competent and responsible citizens. Generation of such a crop of productive professionals, entrepreneurs and workforce for sustainable wealth creation and shared prosperity of humanity is a viable way to improve the national productivity, work ethics and knowledge base of any ailing economy across the world.

Meanwhile, laying a solid foundation for creative entrepreneurship and development of self-reliant nations will require the support of visionary teachers, diligent parents, quality media, functional industries and every citizen to provide the necessary instructional resources, tools, and training of resilient youths as a viable source of our collective strength in nation building. Herein a comprehensive school curriculum becomes a critical imperative in the provision of quality education for sustainable human capacity building, economic diversification and industrial development. Given these contemporary developmental realities in a global learning community for all, Oyekan (1997) identified the notable characteristics of a good curriculum, which include its:

(i) Flexibility to accommodate and cope with the continuing interests, needs and aspirations of learners and their nations 
(ii) Comprehensiveness in providing for academic, vocational and professional programmes to ensure the acquisition of desirable scholarship, employable skills, work ethics and best practices associated with everyday life;

iii. Relevance to the needs and solution to emerging problems of learners and their changing society and;

iv. Susceptibility to formative and summative forms of evaluation in the course of being implemented and reviewed by experienced educators and professional teachers.

The curriculum should be functional, dynamic and responsive to the changing needs, interests, problems and visions of individuals and their developing society. It is expected to refine and nurture intelligent, competent and self-reliant persons that would be able to adjust, transform and sustain the conditions and mechanisms for harnessing the resources in their environment for their wellbeing and betterment of mankind.

Since curriculum is one of the foundational elements of effective schooling and teaching, it is often the object of reforms, most of which are broadly intended to either mandate or encourage greater curricular standardization and consistency across States, schools, grade levels, subject areas and courses (Great Schools Partnership, 2014). Reform means to reshape, review, modify, reconfigure or make different as the basic elements of improving the curriculum and strategies of imparting meaningful learning contents with appropriate instructional resources. Varying conceptions and meanings have been ascribed to curriculum reform at all levels of education. What is curriculum reform? Is it of any relevance to comprehensive education and self-reliant personality of the citizenry? How can curriculum reform prospect quality human life in a sordid period of economic recession? Beyond the total development of functional individuals, curriculum reform might help to inculcate the right knowledge, expertise and values required by brilliant and self-reliant school graduates for gainful living in a safe dynamic environment.

Hence, curriculum reform is the process of modifying learning contents and instructional practices in order to meet the interests of learners and needs of the contemporary society for its sustainable development. From this utility perspective of shared prosperity in a sustainable environment, curriculum reform becomes an enduring vehicle of revitalisation, reengineering and strengthening effective teaching-learning process as an existential platform to refine human capital development. Basic factors which could contribute to meaningful curriculum reforms include experienced professional teachers, educators, learners, subject disciplines and social-cultural values of the society that often emanate from varying social, economic and political activities of the people. It is envisaged that an effective adoption of well balanced curriculum reforms underscores the importance of a paradigm shift from declining fortunes of education and economy to a quality life of prosperity and self-sufficiency in a safe living environment. Therefore, schools need a rapid response strategy to curb the prevailing underachievement, unemployment, corruption, poverty, insecurity and intrusion of social vices ravaging the credibility of subject curriculum implementation and employability of emerging graduates into the changing world of education, business and work.

Entrepreneurship is the wealth creation from skillful development and investment on novel ideas generated by creative individuals to solve critical challenges that will promote their economic wellbeing and enhance the quality of human life. It is anchored on the strength of character of entrepreneurs whose audacity of change and skillful use of their enterprising talents can give them a brighter and rewarding future with greater responsibility for self-reliant employment and wealth creation. Herein enhancement of human capacity development demands adequate comprehensive entrepreneurship education as a basis to identify and develop the creative talents of youths with sufficient resources in academic, vocational and technical subjects within and outside the school settings. Wikipedia (2014) noted that entrepreneurship education seeks to provide students with the knowledge, skills and motivation to encourage entrepreneurial success in a variety of settings. On this premise, meaningful curriculum reforms at all levels of education can expose learners to relevant experiential work-based learning activities in a variety of arts, commercial, science and technical subjects as the groundwork for higher education student' choice of enduring careers from Agriculture, Education, Engineering, Environmental Studies, Humanities, Science and Technology, and Management courses (Oyekan, 2000; 2016). The youths are gradually provided with the wherewithal to ensure technological evolution and economic growth for human survival in a productive society. 


\section{Curriculum Diversification for Entrepreneurship Education}

Post-colonial independent Nigeria is dotted with variegated flashpoints of crisis severally precipitated by poor governance, inadequate quality human resources, infrastructural deficit, economic recession, brazen corruption, unemployment, poverty, religious bigotry, insurgency and insecurity of life and property. Ifionu (2015) is even persuaded that all Nigeria needs is a strong political leadership that is honest, sincere, resilient and ready to mobilise the creative ingenuity of Nigerians in tackling the nation's many challenges. Now is the time for visionary individuals, organisations and governments that are committed to sustainable existential harmony, stability and prosperity which would meet the future needs of Nigerians should embrace continuing investment in quality education as an integral to personal and national development. This is why the provision of decent functional education is one of the most effective egalitarian tools that guarantee transformative capacity development, self-reliant wealth creation, consistent upward social mobility, healthy living, and exceptional destiny of individuals irrespective of their gender, race and financial circumstances. It surely becomes necessary to establish comprehensive schools with inherent belief in qualitative education as an imperative for sustainable development and improvement of humanity.

Hence, the schools at all levels of education should secure the future today with a pragmatic training innovation for the development of enterprising graduates considered professionally competent, productive and worthy in character and learning. Beyond the paper qualifications, Elizade University (2016) is poised to adequately equip their students with vital value-added knowledge experience and relevant entrepreneurial competence required to succeed in life in order:

To avoid the current trend where most graduates possess good paper qualifications but lack the vital

and relevant skills for the work place, (hence,) we have put in place value-add programmes and real

work place training to equip our students to face whatever challenges they encounter in the real world

and excel in their chosen fields of endeavours (p.19).

Realising that people are the bedrock of our existence might have spurred Babcock University to use team spirit in building partnerships which provide holistic education ingrained with knowledge, skills and values to discover and transform potentials, restore hope and create leaders who make the world a better place (Babcock, 2016). A Nigerian training outfit, Knowledge Exchange Centre, further implored the professionals, artisans, business owners and entrepreneurs to equip themselves with the right knowledge, practical skills and industrial experiences to build sustainable strong businesses beyond the current economic recession (The Punch, 2016). These training innovations and expectations of comprehensive human capital development constitute the panacea for massive failure, unemployment, and infrastructural decay, poverty and insecurity across the land.

Education in developed and developing countries of the world is gradually becoming a joint venture between the government and the public in collaboration with private sector initiatives. Herein lies the need to constantly review the planned learning contents to ensure their continued adequacy and relevance to learners' interests, national needs and human problems in a changing world. According to Hurd (1969), it is essential to look at the school in terms of a long-range planning system and at the curriculum as an instrument for individual and social development - not as an end in itself. The development of a highly skilled and socially responsible competent people may result from the provision of diversified school curricula, which are planned in terms of the needs, aspirations and vision of the productive society and eclectic instruction based on core values for human survival in a safe living environment. Emerging meaningful schooling at all levels of education and vocational training will be facilitated by creative teaching and effective learning of relevant subject knowledge, practical life skills and responsive ethical orientations needed to promote economic growth, environmental conservation and sustainable development. With a just balance among the social, economic and environmental needs of present and future generations, progressive nations will support functional schools to achieve the United Nations' Sustainable Development Goal 4 (SDG 4), which is aimed at ensuring inclusive and equitable quality education and promote life-long learning opportunities for all (United Nations Department of Economic and Social Affairs, 2015). This ultimately makes educated people to be at the centre of democratic governance, economic prosperity and moral regeneration towards promotion of efficient classroom practices, industrial growth, dynamic national development and environmental protection for a sustainable future of humanity. 
The quest for quality education, enlightened population and self-reliant school graduates is the enduring guarantee for a prosperous future. Faith in the potential power of education as a universal agent of change and stability ought to be backed up by a high degree of political will, careful planning and sufficient resource support (Oyekan, 1997). Realisation of this objective made Elizade University (2016) to provide a perfect blend of good infrastructure and the best available mix of capable, well exposed, experienced academics and professionals. It is informed by the need to produce a better educated, suitably competent and professionally responsible workforce to meet the emerging manpower needs of an industrialising economy and modernising society within the cultural context of continuing quality education, business ventures and gainful work. Hence, the school should explore and embrace the symbiotic nexus between functional education and gainful work while aiming towards breeding a crop of enterprising and self-reliant citizenry. It implies that functional education ingrained with diversified curriculum shall expose the enterprising and self-reliant citizenry to relevant academic knowledge, technical know-how, and vocational skills necessary for viable agricultural, industrial, infrastructural and political development of the country (Oyekan, 2016). Emerging well-informed, skilled and decent school graduates shall become self-reliant workforce and effective citizens that will help to resolve the prevailing social, economic and political challenges threatening human survival and environmental conservation.

Furthermore, Bajomo (1996) and Oyekan (2016) believed that today's realities and development challenges of nations should constitute the major learning contents in their envisioned curriculum improvement efforts, orientation and empowerment of youths, appropriation of manpower requirements and absorptive capacities of the country. For instance, Post-Basic Education and Career Development (PBECD) is the education children receive after a successful completion of ten years of Basic Education (Federal Republic of Nigeria, 2013). It is usually provided for Basic Education graduates who are not proceeding to Senior Secondary Schools (SSS) as a means of preparing them for the world of work, wealth creation and entrepreneurship. Towards achieving the objectives of PBECD, concrete reforms in learning contents resulted in additional new subjects ingrained with pre-vocational competence and training, entrepreneurial initiatives and work orientations. Hence, the operational curriculum for the SSS consists of:

\section{Compulsory crosscutting subjects, such as English Language, General Mathematics, Trade/Entrepreneurship subject;}

Science and Mathematics, which consist of Biology, Chemistry, Physics, Further Mathematics, Health Education, Agriculture, Physical Education, and Computer Studies;

Technology, comprises Technical Drawing, General Metal Work, Basic Electricity, Electronics, Auto-mechanics, Building Construction, Wood Work, Home Management, and Food and Nutrition.

Humanities, consist of Christian Religious Studies, Islamic Studies, Visual Art, Music, History, Geography, Government, Economics, Literature-in- English, French, Arabic, and Nigerian Language.

Business Studies, made up of Store Management, Accounting, Commerce, Office Practice, and Insurance.

In reality, curriculum diversification will nurture learners that could produce artisans and skilled professionals who might help to diversify the national economy, exploit abundant resources in non-oil sector exemplified by solid minerals, agriculture, hospitality and tourism, sports and entertainment, power and security, and manufacturing industries. Hence, a good curriculum reform creates an equitable platform to integrate national aspirations, community needs, economic trends, and technological innovations in the global efforts to achieve universal and sustainable development with a comprehensive education for all citizens. This underscores a means of investing in people's knowledge and skills today to promote the building of the resilient human capital required for future education, business and work in the $21^{\text {st }}$ century.

\section{Prospects of Curriculum Reforms for Quality Human Life}

The development, stability and prosperity of any nation are related to the quality of continuing qualitative education, entrepreneurial training and ethical orientation given to its productive citizens. Many curriculum changes have in fact been introduced as part of a deliberate and systematic approach for the school to respond selectively to the demands of a dynamic society. The prospects of curriculum reforms for entrepreneurship education and quality human life include:

The school would become an avenue for learners to blend their intellect, skills, values and visions of quality human life; 
Provision of gender parity and equal learning opportunities for all the brilliant, indigent and exceptional students of varying backgrounds;

An educational beacon of lifelong learning for all.

Training of productive workforce for tomorrow's world of education, business and work;

Enhancement of employability and work productivity of school graduates with a greater success in the labour market;

Acquisition of relevant vocational competence, work ethics and employment opportunities for wealth creation, economic prosperity and poverty reduction; and

Provision of vibrant platform for integrated professionalisation, vocationalisation and innovation of learning contents.

Hence, the school would become an avenue for learners to blend their intellect, skills, values and visions of quality life with the changing needs of their living community, industrial economy and democratic polity. The increasing industrialisation, urbanisation, occupational mobility and human diversity continually the necessity for recurrent practical education hinged on vocational training with much impact on the school curriculum. Adequate resources should be invested in curriculum reforms to facilitate integration of educational innovations and technological devices in training programmes that will address the specific needs and ambitions of learners for academic excellence and career development.

Education has a pivotal role to play in the quality of manpower and leaders moulded for good governance, economic growth and wellbeing of the people. Curriculum reforms, with its diversity of subject disciplines, will provide gender parity and equal learning opportunities for all the brilliant, indigent, and exceptional students of varying backgrounds. It is an opportunity to accommodate individual differences, integrate community needs and to fulfill the personal ambition of learners with diversified curricula. Oyekan (2000) envisioned career education as an integral part of modern educational system aimed at incorporating the core and vocational curricula with viable academic guidance. Within this context, Okino (1995) had identified the general apathy to work as a wedge in the realisation of schooling objectives while he proposed the introduction of proper work ethics in our schools. Hence, proposals for a functional education can be accomplished through the use of work which accommodates enduring productivity goals of the society in ways that emphasise the humanising objectives of Nigerian education. This quality lends credence to career education as a vehicle for curriculum reform in moulding productive self-reliant citizenry necessary to boost sustainable democratic leadership and economic growth in a developing technocratic society. The students could be assisted in developing relevant value-added knowledge, enterprising skills and survival strategy to make them accumulate capital out of their earned income from gainful employment.

When effectively implemented with its diversity of learning contents and needs of learners, curriculum reform becomes an educational beacon of lifelong learning for all. It underscores the universal power of diagnosing talents and investing in people's professional knowledge, marketable skills, and ethical values to promote human capacity for a world of shared prosperity, harmony and stability. Hence, curriculum reforms will help in the professional training of vital workforce today for tomorrow's world of education, business and work. The school graduates might have been exposed to salient career information acquired the problem-solving skills and imbibed an enduring philosophy of existential life: work, re-train, love and live at peace with all. Otherwise, the absence of sound philosophy of both work and education may continue to widen the gap between them with attendant evils such as unemployment, poverty, criminality and insecurity; which are plaguing the Nigerian society (Nwankwo, 1981; Okino, 1995; Oyekan, 2016). This underlines the fusion of curriculum reforms, career orientation and entrepreneurial initiatives to prepare skilled and courteous literate manpower for work and the enterprising challenges of life today and tomorrow.

Moving forward as a nation demands the use of common sense and functional resources to solve common problems which affect citizens and management of our commonwealth. It, therefore, behoves the educators, teachers and school administrators to facilitate curriculum reforms to fruition, promote scholastic excellence that could metamorphosise into a tower of sustainable success, self-reliance and prosperity of the society. This requires extensive policy interventions, creative capacity building initiatives, public-private partnerships and supportive community collaborations in sustainable provision of adequate funds, functional infrastructures, viable security architecture and continuing training programmes. Schools should engage in strategic partnerships with training schemes and organisations such as:

United Nations Industrial Development Organisation (UNIDO), 
National Directorate of Employment (NDE);

Industrial Training Fund (ITF);

Nigerian Institute of Training and Development (NITAD);

Government Enterprise and Empowerment Programme (GEEP),

Youth for Technology Foundation (YTF);

N-Power (job creation scheme, http://portal.npoer.gov.ng); and

\section{Organised Private Sector.}

These skills acquisition outfits could create an enabling environment for entrepreneurship, manage apprenticeship, inculcate occupational standards and improve the professional competence of school graduates with requisite work productivity. Such a laudable vision is achievable with the recognition of youths as the strength and future of sustainable development. For President Muhammad Buhari, Nigeria has one of the youngest populations in the world, who are immensely energetic and talented, consistently blazing the trail in the arts, sports, business and technology (Saturday Punch, 2016). With regard to making realistic career decisions, relevant vocational information exposes the prospective workers (i.e. students) to the complementary world of academics and work (Okoye et al, 1990). Beyond the dynamics of labour market, it helps the students to acquire strong socio-emotional abilities (such as self-esteem, self-control, diligence, dedication and responsibility); explore the existence and requirements of quality jobs, identify their vocational potentials, envisage rewarding prospects the jobs hold for them, and think on additional training opportunities on the job. The tendency is to enhance creative entrepreneurial capacity, continuing career improvement, socio-emotional competence and work productivity of the school graduates with a greater success in the dynamic labour market.

Continuing curriculum reforms shall enable the nations to use the prescribed learning contents for intellectual and vocational engagements of learners as a means of nurturing the required manpower needs in public and private sectors of the economy. Learners are provided with vibrant cultural heritage, technological innovations, and creative industrial experiences in their contemporary society. Effective integrated control of the classroom resources, instructional systems (curriculum and instruction), and behavioural system (rules and expectations) creates a nurturing learning for all students (Tavakolian and Howell, 2012). Schools also would become the active participatory generative learning centres that reflect creative interests, new ideas and viable aspirations of learners. The provision of comprehensive education as a reformative process in sustainable development of nations could enhance acquisition of relevant vocational competence, work ethics and employment opportunities for wealth creation, economic prosperity and poverty reduction. As curriculum reforms bring valuable academic improvements, engagement in productive ventures by competent professionals, artisans and entrepreneurs will diversify and strengthen their financial base, which grows the gross domestic products (GDP) for prosperous development of the country.

Hence, curriculum reforms could provide equal schooling opportunities for school-age children with practical tasks, integrated technological devices and diagnostic remediation of identified challenges in learning, economy and society. Such impactful instructional changes might mitigate the proclivity for academic infractions, massive failure in organised institutional and public examinations, brazen corruption with impunity and imprudent management of resources. The curriculum shall be recognised as the heart of comprehensive education as curriculum reforms will facilitate educational innovations, vocational competence, and entrepreneurial training of learners with the core values of humanity. It is intended to provide creative learning tasks, investment initiatives and fruitful opportunities for children and youths to exploit their inherent potentials, achieve their lofty dreams, secure gainful employment and create sustainable wealth that could improve quality human life.

The nexus between curriculum reforms and entrepreneurship education shall provide the vibrant platform for integrated professionalisation, vocationalisation and innovation of learning contents. This could motivate the learners to acquire credible certification, employable competence, professional standards and industrial experiences that would make them self-reliant and self-fulfilled individuals. Such productive and responsible fellows could improve the value-added knowledge base for democratic governance, economic diversification and industrial development of their society. The comprehensive training of resilient youths that expose them to relevant experiential work-based learning activities will become a viable source of sustainable human capacity building, poverty alleviation mechanisms, and technological industrialisation of any 
ailing economy. With an inclusive generation of helpful products and services from decent work, it is envisaged that the strong, energetic and brilliant youths will become the strength and future of sustainable development of quality infrastructure, healthcare, agriculture, renewable energy, clean water, environmental sanitation and technological innovation. This might ease the production of sufficient food and healthy citizens who will help to banish poverty, hunger and diseases across developing nations worldwide. In all, affordable comprehensive education anchored on diversified curricula will be globally recognised as a formidable catalyst to achieve all the SDGs that could enhance effective citizenship, peace, unity and prosperity of nations.

\section{Conclusion}

Education is a powerful tool to harness the inherent human potential and vision for the resolution of economic, social and political challenges confronting the unity, stability and survival of Nigeria. Schools need a rapid response strategy to curb the prevailing underachievement, unemployment, corruption, poverty, insecurity and intrusion of social vices ravaging the credibility of subject curriculum implementation and employability of emerging graduates into the changing world of education, business and work. Meaningful curriculum reforms can expose learners to new thinking and relevant experiential work-based learning activities in a variety of arts, commercial, science and technical subjects as the groundwork for higher education students' choice of enduring careers. This provides the basis to refine the potentials of our human resources with broad-based curricula built on a core of basic academic subjects, pre-vocational studies and co-curricular activities. Such efforts to expand access to comprehensive education aimed at building the solid foundation for renewable entrepreneurial leadership, effective citizenship and successful careers will focus on continuing innovation, creativity and commitment to the wellbeing of learners.

Hence, the provision of functional education is an egalitarian tool that guarantees transformative capacity development, self-reliant wealth creation, consistent upward social mobility, healthy living and exceptional destiny of individuals irrespective of their backgrounds. It is informed by the need to produce a better educated, suitably competent and professionally responsible workforce to meet the manpower needs of an industrialising economy and modernising society within the context of their culture and resources. Therein lies the necessity to recruit well-trained teachers should develop meaningful reading comprehension and study habits that will facilitate effective teaching and conceptual understanding as well as improve students' skills acquisition, educational performance and career development in all subject disciplines. Such creative teachers will use computers, computer- aided progammes and applications software to design lesson plans, facilitate blended learning and enhance excellent achievement of students. For instance, application of value-added knowledge and technological skills in the assemblage of automobiles, industrial machinery, scientific equipment and domestic gadgetry for the production of essential commodities (e.g. food and textile), and quality life services (e.g. building and road construction) can bridge the infrastructure deficit; and complement economic integration and industrialisation drive of many African nations. The government is, therefore, implored to build functional incubation centres which will nurture the young start-up entrepreneurs endowed with talents and ideas to create innovations that deliver value, stimulate industrial growth, and boost the GDP for economic prosperity and national development.

\section{References}

[1] Adamu, A.U. (1994). Educational reforms in Nigeria. Retrieved March 7, 2015;

[2] http://www.kanooline.com/publications/educational_reform_in_nigeria.htm

[3] Awofala, A.O.A. \& Sopekan, O.S. (2013) .Recent curriculum reforms in primary and secondary schools in Nigeria in the new

[4] Millennium, Journal of Education and Practice, 4 (5), 98-107.

[5] Babcock University (2016) The 2016 calendar: Experience our uniqueness. Available: www.babcock.edu.ng

[6] Bajomo, O. (1996) Manpower utilisation in Nigeria: An analysis of causes and consequences of unemployment, First Bank of

[7] Nigeria Bi-Annual Review, 3(8): 74-84

[8] Elizade University (2015) 2015/2016 undergraduate admissions: Beyond paper qualifications, Sunday Punch, August 2, p.19.

[9] www.elizadeuniversity.edu.ng. 
[10] Engelberger, J.F. (1982). Robotics in practice: Future capabilities, Electronic Servicing and Technology Magazine,

[11] Federal Republic of Nigeria (2013) National policy on education, Yaba-Lagos: NERDC Press.

[12] Great Schools Partnership (2014) Curriculum, In S. Abbott (Ed.) The glossary of education reform. Retrieved from:

[13] http://edglossary.org/curriculum, 14th March, 2015

[14] Hurd, P.D. (1969). New trends in teaching secondary school science, Chicago: Rand McNally and Company.

[15] Ifionu, O. (2015). Clinton, Leahy and Nigeria's destiny, The Guardian, Tuesday, July 28, p.21

[16] Kwong, J. Y. \& Kooi, S. N. (1990) Evolution of educational excellence, Singapore: Longman Singapore Publishers, pp.60; 74-79

[17] Nwankwo, J. I. (1981) Do we live to work or work to live? Towards a philosophy of career education in Nigeria, Career, 8(1): 18-27

[18] Okino, A. M. (1995)Bridging the gap between expectations and realities from schooling: Strategies and actions. In Ipaye,

[19] Research on schooling in Nigeria: Introductory readings, Lagos: Chayoobi Printer and Publishers, pp. 225-229

[20] Okoye, N. N.; Adejumo, D.; Achebe, C. \& Obanya, P. (1990) Fundamentals of guidance and counselling, Ibadan: Heinemann

[21] Education Books (Nigeria) Ltd., pp. 119-177

[22] Oyekan, S.O. (1997). Groundwork of curriculum and instruction, Ibadan: Alafas Nigeria Company, pp. 1-12

[23] Oyekan, S.O. (2000). Foundations of teacher education, Okitipupa: Ebun-Ola Printers (Nig.) Ltd

[24] Oyekan, S.O. (2015). Diagnosis and remediation of challenges of education for quality human life in Nigeria, African Journal of

[25] Historical Sciences in Education, 11(1): 261-284

[26] Oyekan, S.O. (2016) Sustaining a diversified economy and combatting security challenges through science and technology

[27] education, Science \&Technology, 2(6): 201-220

[28] Saturday Punch (2016) My government belongs to youths, says Buhari, August 13, p.7. Available on: www.punchng.com

[29] Tavakolian, H.R. \& Howell, N. (2012) School education: A gateway to success.

[30] Journal Educational and Social Research, 2(2):137-142

[31] The Punch (2016) Firm plans empowerment for SMEs, Wednesday, July 6, p.32. Available: www.punchng.com

[32] United Nations Department of Economic and Social Affairs (2015) Open working group proposal for sustainable development

[33] goals. Available on: https://sustainabledevelopment.un.org/owg5.html

[34] Wikipedia (2014) Entrepreneurship education. Available at:

[35] file:///C:/Users/user/Documents/Entrepreneurshipeducation-Wikipedia

[36] World Bank (2016) Education. Retrieved from http://blogs.worldbank.org/education/data 